\title{
From robots to social robots. Trends, representation and Facebook engagement of robot-related news stories published by Italian online news media
}

\author{
Nicola Righetti \\ University of Urbino Carlo Bo \\ nicola.righetti@uniurb.it
}

\author{
Marco Carradore \\ University of Verona \\ marco.carradore@univr.it
}

\begin{abstract}
In recent decades, robots, social robots and artificial intelligence have increasingly entered daily life, affirming their presence not only in traditional spheres such as industrial production, but also gaining access to social reproduction, expressive functions and domestic activities. Considering the social relevance robots have now acquired, this essay aims at investigating their cultural representations in Italian online news media. More specifically, the study investigates trends of robot-related topics in online newspaper coverage and Facebook engagement over time, and analyzes news topics through text mining techniques. The study relies on a dataset of about 3,000 news stories published between 2014 and 2018 by some 100 different Italian news media. Results show a constant increase in news relating to robots, a major interest in work issues and a thematic shift over time: more recent topics describe the social-reproduction functions of robots. Finally, some suggestions for future research are outlined.
\end{abstract}

Key words: social robots, robotics, Facebook, online news, text mining

\section{The social birth of robots}

In recent years technological beings have been entering our individual and social lives in ever increasing numbers. From virtual personal assistants like Microsoft Cortana, Apple 
Siri, Amazon Alexa and Google Home, or the holograms we may encounter during daily activities (Viviani, 2012), to robots working with us (Ljungblad et al., 2012) and for us (McFarland, 2019; Broadbent et al., 2009), artificial creatures are leaving the fictional world they inhabited for centuries and the industrial and aeronautical fields in which they used to be applied, to increasingly share our living space, in a process of robotization that has involved all areas of society (Fortunati, Esposito, Lugano, 2015).

Although society is witnessing an increasing diffusion of machines in the domestic sphere and the automatization of everyday life (Fortunati, 2018), the integration of technological machines in society, far from being an easy process, is a complex interweaving of technological, social and cultural dimensions. Science has been making great progress in improving artificial intelligence and robotics technologies, but technoscientific knowledge is not sufficient to accommodate its creations in social life. Instead, a space in the symbolic order of society needs to be created to include mechanical creatures in socially shared frames of meaning (Moscovici, 2001), to transform them from mere objects to meaningful objects, that is, social objects (Fortunati et al., 2018).

Creating such a cultural space is not an easy process. Especially for technological beings such as humanoid robots. Of all techno-artificial creatures, they may well evoke the strongest reactions due to that similarity to men that elicits powerful, somewhat eerie, sensations (Mori, 1970, 2012; Strait, 2017). Furthermore, the very construction of robots can evoke the darker, deeply rooted social taboos associated with man's promethean desires which inevitably recoil on him because they are in violation of divine or natural law. Technoscientific dystopias are countless in the Western imagination: from Mary Shelley's "Frankenstein" to HAL 9000 artificial intelligence in Arthur C. Clarke’s "Space Odyssey" series, the rebellion of artificial creatures against their creators is a well-known literary topos. Furthermore, media also play a significant role in the process of familiarizing people with robots (Bartneck, 2013; Sundar et al., 2016), representing means of socialization that can assist in overcoming the anxieties otherwise related with the human-robot relationship.

Despite the complex interweave between society and techno-social phenomena, and the major social transformations this can lead to, most of the studies around the topic are 
currently confined within the field of technological disciplines, while only a few tackle the problem from a sociological perspective. In order to contribute to the empirical analysis of the relationship between society and the latest technological developments, this study has focused on the media coverage of robots. More specifically, it has analyzed how, and how much, robot-related topics have been covered and represented in the headlines of Italian online newspapers throughout recent years, relying on text mining techniques for unsupervised textual classification. Besides measuring the media coverage and extracting the topics that dominated discussion (Giglietto et al., 2018; Righetti, 2016; Righetti et al., 2019), attention was paid to registering the number of interactions reached by the news stories shared on Facebook (Giglietto et al. 2019b; Lovari et al., forthcoming; Righetti et al., 2019) - the most widely used social media in Italy (AGCOM 2019) - as a proxy, critically considered (Webster, 2014), for online public attention to the topic.

The paper is organized as follows. In the first section the scientific studies about robotics and their relationship with society are reviewed. Then, the research questions are introduced, along with data and methods used in this study. The subsequent section presents the results of the analyses, followed by their discussion and some hints for future research in this field.

\section{Social studies on robots}

The process by which robots shift from industrial production to everyday life has been rapidly expanding. Robots have branched out from traditional areas (such as space exploration, manufacturing, military and security business, search and rescue work) into new social spheres that involve "the core functions of social reproduction (e.g. care of children, elderly people and the disabled, education, and leisure)" (Taipale et al., 2015: 11), implying a shifting from material to immaterial tasks.

A definition of robot is given by the Robot Institute of America (1979): “A reprogrammable, multifunctional manipulator designed to move materials, parts, tools, or specialized devices through various programmed motions for the performance of a variety of tasks". However, despite the fact that the robot's forerunners can be traced to ancient 
Egypt in the form of automatic machines (e.g. catapults and hydraulic pumps), as stated by Muscato (2011), we are far from a clear and shared definition.

The social transformation process that involves robots and their acceptance depends on the culture of individual countries and their economic, technological and social development. Even though it is also noticeable in Italy (Muscato, 2011), in Asian countries such as Japan (Tsuchiya, 2015), the "robot culture" has been gaining ground for many years, not least because ancient Japanese religious principles are very different from the Christian ones that shaped Italian society. Indeed, Shintoism does not distinguish between beings with and without a soul, such as animals and objects, a distinction fundamental to the Christian religion and to the societies exposed to its influence. It marks a cultural divide which has deep consequences for how societies view non-human beings (Righetti, 2018, 2019) and which influences both the acceptance of robots and research into them (see Hornyak, 2006, p. 29).

Thus, while in Japan robots share the same dignity as human beings and are widely accepted and integrated into daily life (Bartneck, 2005; Operto, 2011, p. 105), Western society seems to be more diffident about them. In a recent survey in the United States, Pew Research Center (2017) found that Americans are worried that robots might replace human jobs $(72 \%)$ and fear algorithms that could be used for hiring and assessing job candidates (67\%). To a lesser extent they are worried about driverless vehicles (54\%), and robot caregivers for older adults (47\%). The survey also revealed that higher levels of education are associated with a more positive view of workplace technologies. However, the public generally expects a negative social impact from jobs automation.

Regarding Europe, some insights into the social perception of robots can be found in the Special Eurobarometer 382 (which refers to the 2012 data of 27 EU member states). Most EU citizens $(70 \%)$ have a positive view of robots (56\% "fairly positive" and $14 \%$ "very positive"), a percentage that varies across countries. EU citizens having a positive view of robots range from about 55\% in Greece and Malta to about 90\% in Denmark and Sweden. To sum up, people living in northern European countries have more positive views than those living in southern countries. The most recent Eurobarometer survey (carried out in 
2014), illustrates a generally positive view of robots (64\%), though depicting a slight decrease since 2012 , when $70 \%$ of EU people said they had a positive view of robots. The Italian value $(63 \%)$ is approximately the same as the EU mean (64\%). However, EU citizens have limited direct experience of robots: only $6 \%$ of respondents have ever used a robot at home or work. Familiarity with robots is more evident in Slovakia (20\%), Poland (19\%), Slovenia and Italy (both 18\%), Denmark and Finland (both 17\%). Italians who claim to have specific experience of home robots are only $14 \%$ of the population.

The Eurobarometer survey also identified the areas where citizens believe robots should primarily be used. European citizens prefer the use of robots for dangerous jobs and useful tasks such as space exploration, manufacturing, military security, and search and rescue. On the other hand, care of children (as well as care of the elderly and disabled), leisure and education are the areas where EU citizens are far less disposed to believe robots should be used as a priority. These areas may well be considered as primarily "human". The data referring to Italian citizens express approximately the same trend. The only exception was their response to the use of robots in manufacturing which registered twenty points less.

Despite the increasing advances in technology and the growing social awareness of the impact of robots on personal and social life, there remains a lack of research designed to analyze the topic from a sociological perspective, especially in Italy, where the few experiences in the field are circumscribed at a subnational level. Fortunati and colleagues (2015, 2018), for instance, worked on young people's perception of robots by collecting data in Northeast Italy. Recently, centers devoted to the study of the topic have been set up, such as those based in southern Italy (Nicolosi 2011) and northern Italy (such as the "Behavioral simulation and educational robot laboratory Luciano Gallino" at the University of Turin).

In the light of the technological transformation process of society and the lack of research, it seems relevant to start examining this field in greater depth. This study focuses, more precisely, on media coverage and representation of robots. It is an important perspective on the phenomenon since the media contribute to the spread of innovation (Garrison, 2001) and participate in the production of social representations through which 
social objects that are new, and thus strange and threatening, are created and accommodated within the cultural background (e.g. Moscovici, 2001). The study described on the following pages analyzes Italian online media coverage of robots in the last five years, using text mining techniques mixed with qualitative content analysis in order to shed light on how and how much robot-related topics are discussed.

\section{Research questions, data and methods}

This study tackles the following two research questions:

RQ1) Did the online newspaper coverage of robot-related topics and the respective Facebook engagement increase over time?

RQ2) What topics characterized the newspaper coverage and gained more Facebook engagement?

To answer these questions robot-related news stories published by a comprehensive set of national and regional Italian media were collected from $1^{\text {st }}$ January 2014, until $1^{\text {st }}$ January 2019 through Media Cloud, an open access platform for media monitoring that gathers and stores news items published by collections of media sources around the world. The number of news media that the available collections include varies over time and from nation to nation. In the case of Italy, only a small set of sources was available before 2014, while after 2014 their number increased substantially. To avoid the lack of representativeness conceivably associated with too small a news media dataset, data was collected starting from 2014 and including the most complete number of years available.

Media Cloud was queried so as to collect all the available news articles mentioning a set of predefined keywords in their news headlines ${ }^{1}$. Two datasets were downloaded. The first one included the daily frequencies of all the news stories included in Media Cloud and those of the robot-related news items only. This data was used to answer the first research

\footnotetext{
${ }^{1}$ The following keywords were used: "robot", "robots", “androide" (android), "androidi" (androids), "umanoide" (humanoid) or "umanoidi" (humanoids).
} 
question about the coverage of robot-related stories over time (RQ1). The second dataset included URLs, media sources, date of publications and headlines of the news articles. This dataset was used to extract news topics (RQ2) by analyzing the news headlines, short texts that immediately frame and summarize the content, which have already been usefully exploited in much research (see for example: Giglietto et al., 2019a, 2019b; Li et al. 2015; Lovari et al., forthcoming; Righetti et al., 2019; Tartaglia et al., 2006, Vestergård, 2011). The URLs dataset - which after data cleaning comprised 2,672 news items published by 106 online news media sources (Tab. 1) - was supplemented with the Facebook engagement (comments, shares and reactions) of the news stories gathered by querying the Facebook Graph API during March 2019². Just 8.42\% of news stories were without engagement, meaning that no one ever shared them on Facebook.

Tab. 1. News media within the dataset and number of news items of each.

\begin{tabular}{ll|ll|ll}
\hline News media & $\mathrm{N}$ & News media & $\mathrm{N}$ & News media & $\mathrm{N}$ \\
\hline adnkronos.com & 289 & laprovinciadicomo & 16 & corrieredellosport.it & 5 \\
repubblica & 184 & ilpiccolo & 16 & bari-repubblica & 5 \\
ilSole24ore & 184 & ansa.it/en & 16 & lasentinella & 4 \\
ansa.it & 177 & milano-repubblica & 15 & laprovinciapavese & 4 \\
ilmessaggero & 156 & liberoquotidiano.it & 15 & lanuovaferrara & 4 \\
ilsecoloxix & 137 & ilmattino.it & 15 & Il Grecale & 4 \\
iltirreno & 124 & laprovinciadilecco & 14 & Il Friuli & 4 \\
italiaoggi & 76 & Il Denaro & 14 & Brescia 7 & 4 \\
ilgiornale & 67 & corriere & 13 & avanti & 4 \\
AGI & 66 & roma-repubblica & 12 & palermo-repubblica & 3 \\
iltempo & 61 & nuovavenezia & 12 & Il Resto del Carlino & 3 \\
agi & 60 & ilmanifesto.info & 12 & Il Giornale di Brescia & 3 \\
lagazzettadelmezzogiorno & 44 & ilcentro & 12 & corrierealpi & 3 \\
GazzettaDelSud & 43 & avvenire & 12 & Vicenza Today & 2 \\
panorama & 41 & varesenews.it & 11 & tempi.it & 2 \\
internazionale & 39 & napoli-repubblica & 11 & napolitoday.it & 2 \\
LaNazione & 33 & gazzettadimodena & 11 & ligury & 2 \\
torino-repubblica & 32 & romatoday.it & 10 & Liguria Notizie & 2 \\
bologna-repubblica & 32 & IlGazzettino & 10 & La Riviera & La Nuova Periferia - Italy \\
affaritaliani.it & 31 & gazzettadireggio & 9 & Italpress & 2 \\
tgcom24.mediaset.it & 30 & trentinocorrierealpi & &
\end{tabular}

2 Since the news stories were published at different times, it was noticeable that, theoretically, Facebook users had the opportunity to interact with the oldest news for a longer period than with the more recent items, resulting in biases that disqualify attempts to compare the engagement of news published at different times. However, it can be argued that this is only rarely the case. Facebook posts seem to reach their peak of engagement very quickly (Fiebert et al. 2014). Moreover, checking in June 2019 the engagement of a random set of URLs published in December 2018, no difference emerged compared with the same data collected in March 2019. 


\begin{tabular}{|c|c|c|c|c|c|}
\hline firenze-repubblica & 28 & bresciaoggi & 9 & Il Giornale di Lecco & 2 \\
\hline genova-repubblica & 27 & Treviso Today & 8 & viaemilianet & 1 \\
\hline messaggeroveneto & 26 & Italy News & 8 & Varese 7 & 1 \\
\hline La Gazzetta di Parma & 25 & Padova Oggi & 7 & Sicilia News 24 & 1 \\
\hline gazzettadimantova & 25 & opinione & 7 & Novara Oggi & 1 \\
\hline mattinopadova & 24 & larena & 6 & milanotoday.it & 1 \\
\hline it.notizie.yahoo.com & 24 & laprovinciadisondrio & 6 & lanuovasardegna.gelocal.it & 1 \\
\hline tribunatreviso & 23 & espressorepubblica & 6 & lacittadisalerno & 1 \\
\hline lasicilia & 23 & tuttosport.com & 5 & IlGiornaleDiCalabria & 1 \\
\hline IlFoglio & 23 & rainews.it & 5 & ilcittadino & 1 \\
\hline ecodibergamo & 23 & radio24.ilsole24ore.com & 5 & Il Nuovo Levante & 1 \\
\hline ladige & 22 & ilgiorno.it & 5 & Il Giornale di Sondrio & 1 \\
\hline UnioneSarda & 21 & gazzetta & 5 & Il Corriere del Sud & 1 \\
\hline lastampa.it & 17 & Firenze Today & 5 & Giornale - Italy & 1 \\
\hline
\end{tabular}

To answer the first research question concerning the trend of the news coverage on robots, the daily frequencies of robot-related news stories were aggregated by month and then normalized as proportions of the total number of Italian news stories collected by Media Cloud about all the topics. This was done with a view to neutralizing the fluctuation in the quantity of news on robots, caused not by an increased or decreased attention to the topic, but only by the inclusion or exclusion of media sources in the Media Cloud collection. The resulting time series was then decomposed, and the "trend" component extracted (Cleveland et al., 1990). Also the Facebook engagement trend was extracted, using the average engagement by months to account for the oscillation in the quantity of news items that had been published.

In order to identify the main topics discussed in the news (RQ2), a document-termmatrix was built with the lemmatized nouns, adjectives, verbs, adverbs, and terms unrecognized by the lemmatizer, of the news headlines (Righetti et al., 2019). K-means - a popular text clustering algorithm (Aggarwal, Zhai, 2012; Feldman, Sanger, 2007) - was computed on the cosine distance matrix between documents (Aggarwal, Zhai, 2012; Feldman, Sanger, 2007; Giglietto et al., 2018). K-means requires the researcher to specify the number of clusters and is sensitive to the starting point. Therefore, different solutions were tested, choosing the best starting point among 75 random start initializations for each one. The solution with 100 clusters balanced the consistency and coherence of clusters and 
their overall quality ${ }^{3}$. To be sure not to forget any main topic, a new k-means was run on the residual cluster, and another analysis was run again on the residual cluster which emerged from the earlier procedure. Finally, following an inductive approach (Strauss, Corbin, 1998), the news headlines in each cluster were read and labelled according to their main subject, and the clusters eventually grouped in topics and sub-topics. An analysis of lexical specificities performed through the software IRaMuTeQ (Ratinaud, 2009) allowed us to validate the interpretation of the topics by looking at the most characterizing lemmata. Then the engagement of the topics was assessed in order to gain some insight into audience interests.

\section{Results}

This section illustrates the results of the analyses, starting from the first research question on news coverage and trends about robots and their engagement (RQ1), and continuing with the description of the topics and their relative engagement (RQ2).

\subsection{News coverage}

According to the results which emerged from analysis of the Media Cloud dataset, online media have progressively increased their attention to robots: there were 323 news items in 2014, 388 in 2015, 497 in 2016, 633 in 2017 and 829 in 2018. The total engagement on Facebook also increased over time, in tandem with the higher number of news items published and shared on the platform (Fig. 2).

Also the monthly coverage of robot-related topics, which climaxed in 2016 and around 2018, shows an upward trend from January 2014 onward, albeit with some signs of decline during 2017 and 2018 (Fig. 2). The trend could be interpreted as the result of a growing awareness of the relevance of robotics in social life, while the oscillation may be traced back to specific events which galvanized the press during certain periods.

\footnotetext{
${ }^{3}$ The clustering results $(\mathrm{k}=10,20,30,50,100,200$ and 300) were compared via common evaluating statistical measures such as average silhouette width and sum of squares, considering the numerical consistency of clusters and how many documents failed to be classified, thus being included in the "residual" cluster, and inspecting them to assess their semantic coherence.
} 
Fig. 1. News coverage and Facebook engagement by year.
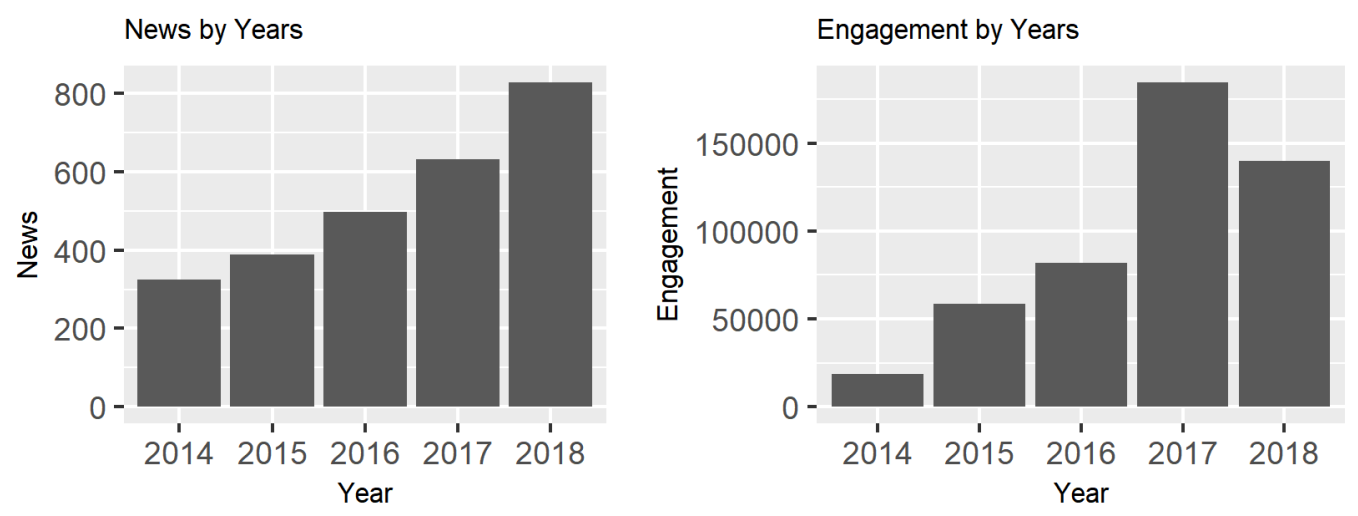

Fig 2. Percentage of robot-related Italian news stories out of the total Italian news stories collected by Media Cloud over time, and the trend component of the time series.
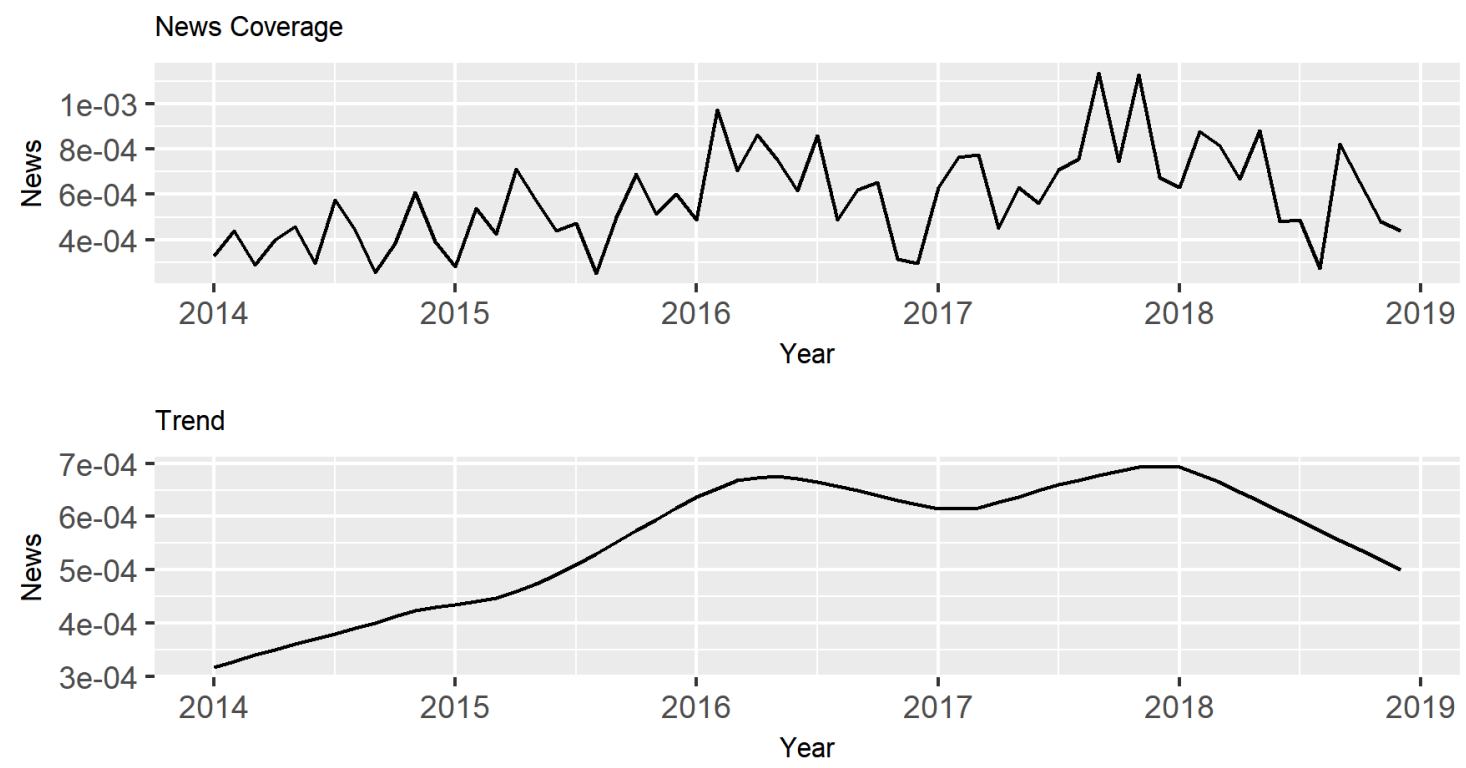

Regarding the news engagement, the trend followed nearly the same pattern of fluctuations, though indicating a more pronounced decline in recent years (Fig. 3). Considering the average engagement by years, after an irregular but always positive increment in engagement from 2014 until 2017, 2018 shows 48\% less engagement than 2017. The reason is due to a news published in 2017 that reached the highest engagement $(67,819)$ among all the news stories in the dataset. Removing this outlier, 2018 shows $20 \%$ more engagement than 2017. Also considering only the news with above average engagement, a clear upward trend emerged. Overall, the results support the idea that online 
media have been increasingly covering robot-related news stories, and the public has been increasingly affected by this.

Fig. 3. Facebook engagement of robot-related Italian news stories and the trend component of the time series (first row), and time series with trend component of the news with engagement above the mean (second row).
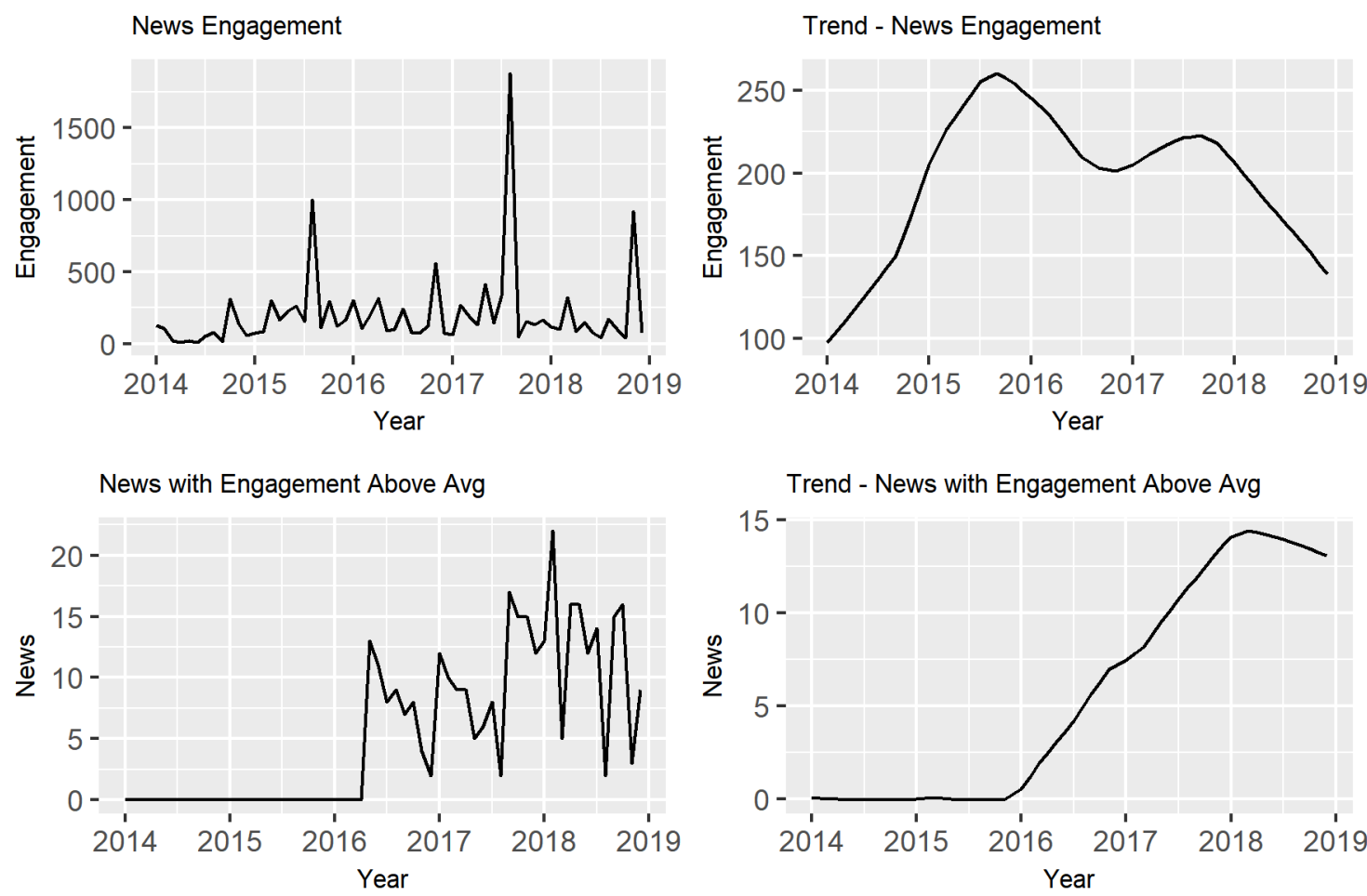

\subsection{News topics}

Recurring themes emerged from the cluster analyses results. The table 2 shows the main topics and sub-topics (RQ2), along with a short description, the ID-code of the clusters included in the class, some examples of the news headlines, the number of news items comprised within each topic (see also Fig. 4) and some descriptive statistics on Facebook engagement. The specificities table (Tab. 3) shows the most characterizing lemmas of each topic while the subsequent table (Tab. 4) shows the ten news stories that gained the most engagement.

The Italian online news landscape centered on robotics appears to be clearly dominated by work-related issues. A first sub-topic in this macro area is labeled "Work Skills" because a substantial number of articles were about robots able to perform jobs with the same capacity as humans: chef, butler, waiter, barman, policeman, soldier, shop assistant, but also the most expressive, creative, spiritual, and thus human jobs, such as dancer, orchestra 
conductor and priest (see Tab. 2 for some examples). The extraordinary abilities of robots seem to be considered newsworthy by news media, and indeed the topic is the one most treated across the years (see Fig. 5). Often newspapers highlight the newness of what they are going to introduce with catchy formulas that sound like "here come the robots!".

Among the professions and activities robots can engage in, those related to health are markedly prominent. Robots can be nurses and surgical assistants, employed in rehabilitation and for assisting people affected by many diseases. Elderly care as well as other health-related work is indeed one of the main applications of social robots, and there are plenty of studies in this field (e.g. Vitanza et al., 2019; Vercelli et al., 2018).

The news on specific cases of companies that employ robots, even to perform jobs sometimes previously done by humans but with more efficiency, are clustered in "Work Company Cases", a topic strictly intertwined with that on "Controversies and Policies", which includes news stories pointing out robots as fearsome competitors of human workers, whose introduction has been leading to negative social consequences in terms of human-job losses (Dekker et al., 2017). Here, the popular trope of the "job-stealing robots" can be read along with political discussions of policies aimed at tackling this issue, like the "robottax". We thus assist at an online scenario dominated by news stories that leverage on the widespread fear that robots will steal human jobs (Pew Research Center, 2017). It is therefore not surprising that one of the news stories with the highest Facebook engagement is included in this category. It is a news item published by the economics newspaper "IlSole24Ore.com" that is entitled: "UN alarm: robots will replace 66\% of human labor" (Facebook engagement: 6,240). 
Fig. 4. News topic frequencies (category "Other" is omitted).

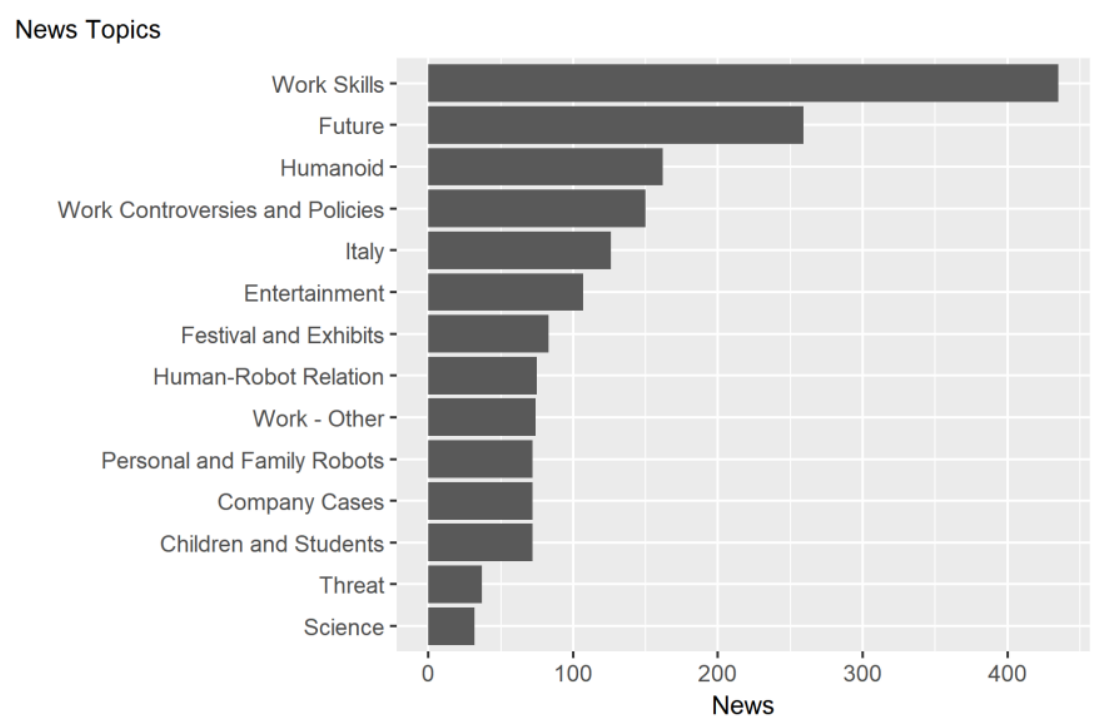

Generally, the overall media scenario is characterized by a look into the future: many stories highlighted newness and innovation - features traditionally associated with technological development - and depicted possible social scenarios along with their implications. These kinds of news are specifically aggregated into the topic labeled "Future", whose headlines are marked by the recurrence of words like "revolution", "new", "the first", "become", and obviously "future" (Tab. 5). Within the class there is also news with a high engagement (18,275 Facebook interactions), entitled: "China: the first robot television journalist presented".

Fig. 5. Topics by year.

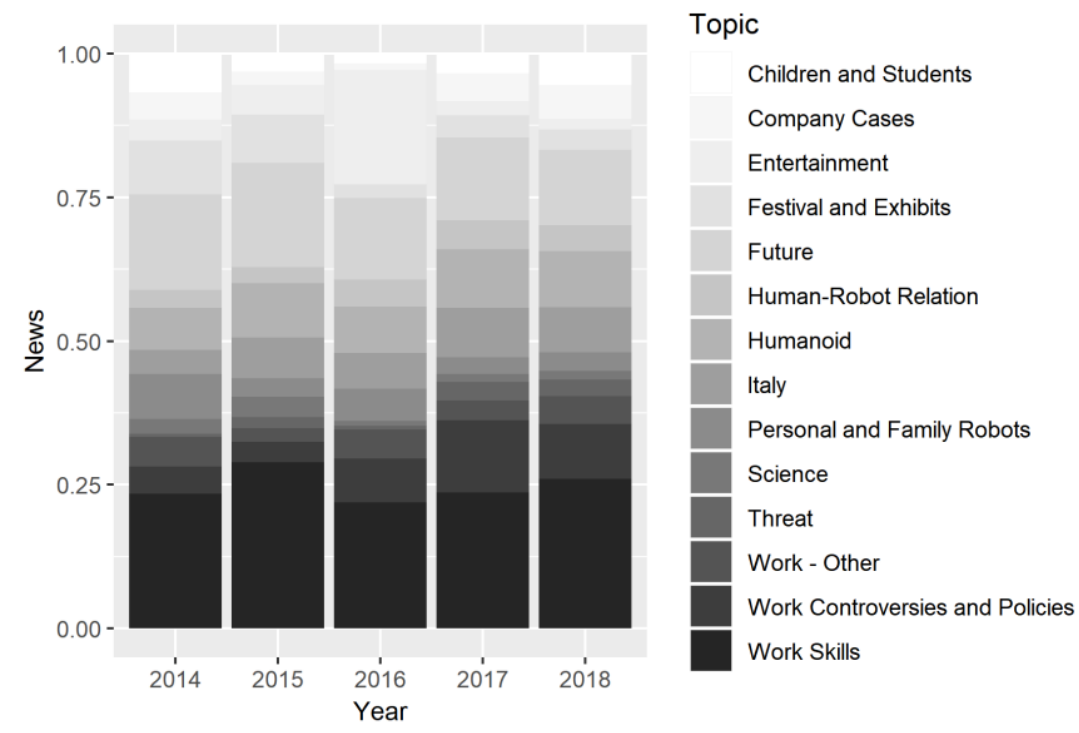


In a framework where a technological future met the increasing ability of machines, news stories stressed how close robots are to humans by discussing the creation of humanoid robots and the evolution of artificial intelligence and sensitivity. In the class "Humanoid" there were described increasingly human-like robots, with human shape and similar physical abilities, able to speak, to think, and to get excited just like any human does. Noticeably, this is the class with the highest average engagement on Facebook. This is mainly due to a highly engaging article which is also the one with the highest engagement among all the articles within the entire dataset. It received more than 65,000 interactions, was published by the newspaper "Il Messaggero" and was entitled: "Two robots start talking to each other in an unknown language: the Facebook experiment is suspended".

Topic "Entertainment" comprises news about media products such as movies featuring robots or recalling the associated imaginary. The mediatization of robots clearly represents a strong vehicle of socialization able to familiarize people with robots thereby reducing their anxieties (Sundar et al., 2016), as also shown by oriental societies, where robots are well integrated and widely accepted and that feature the presence of robots in many leisure and mediatic spaces, such as Japanese cartoons.

The national dimension emerges in the news items included in the topic "Italy" which devoted attention to the role of the country in technological development and industrial competition, celebrating the successes of "made in Italy" in robotic development.

The relationship between humans and robots emerges in the news headlines grouped in the topic "Human-Robot Relations". Here the news tackles the relationship between men and machines from a relational perspective, such as the right way to behave with them and the need for sensitive robots, but also from a legal perspective, related to the rights and duties of robots. A group of news items also wrote about "sex-robots", which have made sexual intercourse with commercial robots possible (Levy, 2009). Similar to the "Humanoid" topics, also this group of news items that blurs the boundaries between humans and machines featured some highly engaging news. It is indeed a news item published by "Internazionale.it" on sex-robots: "Here come the sex-robots" (Facebook engagement 11,159). 


\begin{tabular}{|c|c|c|c|c|c|c|c|}
\hline & & & & & \multicolumn{3}{|c|}{ Facebook Engagement } \\
\hline Topic & Description & Clusters & Examples & $\mathrm{N}$ & Total & Avg & Mdn \\
\hline $\begin{array}{l}\text { Children and } \\
\text { Students }\end{array}$ & $\begin{array}{l}\text { Children and student } \\
\text { activities with robots }\end{array}$ & $\begin{array}{l}17,38,44.18 \\
44.14 .24 \\
44.14 .41,67\end{array}$ & $\begin{array}{l}\text { "Bee-robots let children play and learn. Even those with disabilities" } \\
\text { "The robot that helps children with cancer attend school" } \\
\text { "RLab, science at school: my robot dances rock" } \\
\text { "Tablets and robots in the classroom, inaugurated a hi-tech school in } \\
\text { Milan" }\end{array}$ & 72 & 5409 & 79.54 & 11 \\
\hline $\begin{array}{l}\text { Company } \\
\text { cases }\end{array}$ & $\begin{array}{l}\text { Cases of companies that } \\
\text { employ robots and } \\
\text { related controversies }\end{array}$ & $\begin{array}{l}3,6,44.14 .14,77, \\
91\end{array}$ & $\begin{array}{l}\text { "Robot hired by Ikea to conduct job interviews: it's called Vera and can } \\
\text { do } 150 \text { interviews a day" } \\
\text { "Foxconn will use robots to produce iPhones" } \\
\text { "Only robots will work in call centers in a year?" }\end{array}$ & 72 & 6994 & 102.85 & 20 \\
\hline Entertainment & $\begin{array}{l}\text { News about films and } \\
\text { other media products } \\
\text { featuring robots }\end{array}$ & $\begin{array}{l}44.5,44.14 .25 \\
44.14 .27,45,55 \\
61,63,66,92\end{array}$ & $\begin{array}{l}\text { "They called him Jeeg Robot, the film made in Rome triumphs at the } \\
\text { Davide awards" } \\
\text { "Mr. Robot, the TV series becomes a video game" }\end{array}$ & 107 & 19623 & 202.30 & 5 \\
\hline $\begin{array}{l}\text { Festivals and } \\
\text { Exhibits }\end{array}$ & $\begin{array}{l}\text { Festival and other event } \\
\text { dedicated to robots or } \\
\text { with their presence }\end{array}$ & $\begin{array}{l}11,44.14 .1 \\
44.14 .7,48,70 \\
90\end{array}$ & $\begin{array}{l}\text { "Bologna, the RoBot Festival is back. For the first time at the Fair" } \\
\text { "At the start of 'Human vs Robot', futuristic design shows off in Milan" }\end{array}$ & 83 & 6677 & 90.23 & 6.5 \\
\hline Future & $\begin{array}{l}\text { Scenarios linked to } \\
\text { technological } \\
\text { innovation }\end{array}$ & $\begin{array}{l}4,21,29,36 \\
44.6,44.15 \\
44.14 .34,62,72 \\
83,89\end{array}$ & $\begin{array}{l}\text { "Geminoid, } 7 \text { things to know about the robot revolution" } \\
\text { "Robots, reincarnations, virtual technology: in the future everything will } \\
\text { change except man" } \\
\text { "Octobot is coming, the first soft robot" }\end{array}$ & 259 & 41148 & 171.45 & 13.5 \\
\hline Humanoid & $\begin{array}{l}\text { Intelligent, } \\
\text { communicative, } \\
\text { emotional and } \\
\text { particularly skilled } \\
\text { robots with human } \\
\text { shape and features } \\
\end{array}$ & $\begin{array}{l}25,32,42,44.2 \\
44.14 .15,56,59 \\
84,88\end{array}$ & $\begin{array}{l}\text { "Robots will be able to think and get excited like us" } \\
\text { "Two robots start talking to each other in an unknown language: the } \\
\text { Facebook experiment is suspended" } \\
\text { "Robot solves Rubik's cube in less than a second" } \\
\text { "The monstrous (and human) ability of robots" } \\
\text { "Achires, the robot runs like a human being" }\end{array}$ & 162 & 85499 & 589.64 & 16 \\
\hline $\begin{array}{l}\text { Human- } \\
\text { Robot } \\
\text { Relations }\end{array}$ & $\begin{array}{l}\text { Obligation, risks, } \\
\text { frontiers and human- } \\
\text { robot relationship }\end{array}$ & $26,31,37$ & $\begin{array}{l}\text { "We must learn to be kind to our robots" } \\
\text { "The man and the robot, allies of the future" } \\
\text { "Robots to have sex within a year', but opponents ask to ban them" } \\
\text { "The EU proposal: 'Rights and duties also for robots"” }\end{array}$ & 75 & 23428 & 329.97 & 31 \\
\hline Italy & $\begin{array}{l}\text { News about Italy and } \\
\text { robot production or use }\end{array}$ & $51,57,71,79,87$ & $\begin{array}{l}\text { "Is Italian the language that makes robots work together?" } \\
\text { "Robot, made in Italy grows by 19\%: a better pace than Germany, Japan } \\
\text { and the USA" } \\
\text { "The flexible robot: the first patent in the world is made in Italy" }\end{array}$ & 126 & 20139 & 173.61 & 29.5 \\
\hline $\begin{array}{l}\text { Personal and } \\
\text { Family } \\
\text { Robots }\end{array}$ & $\begin{array}{l}\text { Robots employed for } \\
\text { domestic service, with } \\
\text { practical or expressive }\end{array}$ & $\begin{array}{l}1,44.13 \\
44.14 .17,68,93\end{array}$ & $\begin{array}{l}\text { "Japan: Toyota aims to install a robot in every home" } \\
\text { "The robot dog for the family is coming: it will be on the market in } \\
\text { 2019" }\end{array}$ & 72 & 5789 & 87.71 & 14 \\
\hline
\end{tabular}




\begin{tabular}{|c|c|c|c|c|c|c|c|}
\hline & functions & & "'Company robots, ready to enter our homes" & & & & \\
\hline Science & $\begin{array}{l}\text { Use and creation of } \\
\text { robot by scientist and } \\
\text { researcher (e.g. space } \\
\text { missions) }\end{array}$ & $\begin{array}{l}8,40,44.14 .38 \\
97\end{array}$ & $\begin{array}{l}\text { "NASA, the super-technological robot: it will photograph Mars in 2021" } \\
\text { "Philae has been found, the European robot 'lost' on comet 67P" } \\
\text { "Climate: CNR, with robot and drone team scientists studying polar } \\
\text { ecosystems" } \\
\text { "Fish-robot in the lagoon to monitor waters" }\end{array}$ & 32 & 6815 & 235 & 11 \\
\hline Threat & $\begin{array}{l}\text { Fear of robots and } \\
\text { robotic-related dangers } \\
\text { (e.g. robot soldiers) }\end{array}$ & $\begin{array}{l}13,27,44.7 \\
44.14 .23 \\
44.14 .48\end{array}$ & $\begin{array}{l}\text { "How to stop the robot apocalypse" } \\
\text { "Who's afraid of a robot magistrate? It's not science fiction, it already } \\
\text { happens" } \\
\text { "Robot soldiers are scary: 'With them wars "will be crueler"” }\end{array}$ & 37 & 7705 & 220.14 & 14 \\
\hline Work - Other & $\begin{array}{l}\text { News on the use of } \\
\text { robots for work and } \\
\text { related consequences }\end{array}$ & $\begin{array}{l}16,43,44.3, \\
44.11,44.16\end{array}$ & $\begin{array}{l}\text { "Alarm for Industry 4.0, robots are vulnerable to cyber criminals" } \\
\text { "Volkswagen employee killed by robot" } \\
\text { "Welfare to rethink with robots at work" }\end{array}$ & 74 & 10798 & 161.16 & 17 \\
\hline $\begin{array}{l}\text { Work } \\
\text { Controversies } \\
\text { and Policies }\end{array}$ & $\begin{array}{l}\text { Controversies about job } \\
\text { losses and taxation of } \\
\text { robots that steal jobs }\end{array}$ & $\begin{array}{l}2,10,41 \\
44.14 .39,50,64 \\
81,98\end{array}$ & $\begin{array}{l}\text { "Milan, company dismisses invalid worker: in his place a robot" } \\
\text { "Robots put seven million jobs at risk" } \\
\text { "The proposal: «Robots pay taxes and contributions»" }\end{array}$ & 150 & 39863 & 276.83 & 50.5 \\
\hline Work Skills & $\begin{array}{l}\text { Descriptions of the } \\
\text { work capability of } \\
\text { robots, e.g. chef, butler, } \\
\text { barman, orchestra } \\
\text { conductor and dancer, } \\
\text { with special attention to } \\
\text { the use of robot for } \\
\text { surgery, nursing and } \\
\text { other health purposes }\end{array}$ & $\begin{array}{l}5,7,9,14,18,22, \\
23,30,33,34,35, \\
39,44.8,44.14 .5, \\
44.14 .8,44.14 .10, \\
44.14 .30, \\
44.14 .45,44.19, \\
44.20,47,53,54, \\
58,60,65,74,78, \\
82,86,94\end{array}$ & $\begin{array}{l}\text { "Here comes a robot butler. It's Italian and it will cost like a TV" } \\
\text { "Andrea Bocelli sings directed by a robot conductor" } \\
\text { "Germany, here comes the robot priest" } \\
\text { "From start-up to autism care with a robot" } \\
\text { "There is a lion in the operating room: record surgical intervention in } \\
\text { Lodi with the help of a robot" } \\
\text { "Bologna, in the hospital there is Marino: the robot that teaches little } \\
\text { patients not to be afraid" } \\
\text { "Sad and old Japan, the robot is needed to smile: 'Pepper' flies off the } \\
\text { shelves, automaton with a heart" }\end{array}$ & 435 & 53176 & 131.95 & 12 \\
\hline Other & $\begin{array}{l}\text { Cluster on specific } \\
\text { topics and not well- } \\
\text { defined ones }\end{array}$ & $\begin{array}{l}12,19,20,24,28, \\
44.4,44.12,44.9, \\
44.14 . x x, 44.17, \\
49,52,69,73,75, \\
76,80,85,95,96, \\
99,100\end{array}$ & & 916 & 150320 & 182.43 & 11 \\
\hline
\end{tabular}


Coherently with the fact that youth are increasingly exposed to robotics (Fortunati et al., 2018), it is not surprising that news on robots also dealt with fundamental social institutions like school. This is the case of the headlines included in the "Children and Students" topic, describing how young people experience robots in technological laboratories, exhibits or other educational circumstances, and how they have been getting involved in an enculturation process that socializes them to their everyday presence.

The spreading of robotics is taken into consideration with regard to personal and family life ("Personal and Family Robots") where robots started to be available for many activities (Fortunati et al., 2015; Fortunati, 2018), from the more practical to the more expressive ones.

The analysis found also a specific group of news items on science, where robots are employed, for instance, in the more "traditional" context of space explorations ("Science") and, finally, a small group of news items was specifically concerned with robots considered as a danger for humanity. This news was classified in the "Threat" topic and the news it comprises is mostly about robot killers and soldiers, alluding to the dark apocalyptic imaginary of heartless robots programmed to murder and destroy.

Tab. 4. Top 10 most engaging news stories.

\begin{tabular}{llll} 
Rank & Title & $\begin{array}{l}\text { Facebook } \\
\text { Engagement }\end{array}$ & Topic \\
\hline 1 & $\begin{array}{l}\text { Two robots start talking to each other in an unknown language: the } \\
\text { Facebook experiment is suspended }\end{array}$ & 67819 & Humanoid \\
2 & $\begin{array}{l}\text { Found by the robots Marco Boni. Dead at the bottom of the lake } \\
\text { Robot genes in Naples win a US competition but the school does not have } \\
\text { the money for the trip }\end{array}$ & 22938 & Other \\
4 & China: presented the first robot television journalist & 18275 & Other \\
5 & Here come the sex-robots & 11159 & $\begin{array}{l}\text { Future } \\
\text { Relation }\end{array}$ \\
6 & UFO Robot Goldrake turns 40 years old & 7876 & $\begin{array}{l}\text { Other } \\
\text { Work - } \\
\text { Controversies } \\
\text { and Policies }\end{array}$ \\
8 & UN alarm: robots will replace 66\% of human labor & 6240 & Threat \\
9 & $\begin{array}{l}\text { Appeal to the UN: "Stop robot-soldiers, they are a danger to humanity" } \\
\text { The world's first (free) robot lawyer opens office. His specialty is to } \\
\text { challenge fines }\end{array}$ & 5759 & Other \\
& Hannes, the perfect-grabbing robot hand & 5658 & Other
\end{tabular}


Tab. 5. Specificity table. The most characteristic lemmas in each topic.

\begin{tabular}{|c|c|c|c|c|c|c|c|}
\hline $\begin{array}{l}\text { Children and } \\
\text { Students }\end{array}$ & Company cases & Entertainment & $\begin{array}{l}\text { Festivals and } \\
\text { Exhibits }\end{array}$ & Future & Humanoid & $\begin{array}{l}\text { Human-Robot } \\
\text { Relation }\end{array}$ & Italy \\
\hline School & Amazon & Call & Maker Fair & New & Humanoid & Men & Italian \\
\hline Child & Google & Santamaria & Festival & Become & Intelligence & Sex & Italy \\
\hline Student & Ikea & David & Night & Power & Human & Duty & IIT \\
\hline Little & Piaggio & Mr. Robot & Exhibit & Technology & Artificial & Tell & Made in Italy \\
\hline Learn & Produce & Cinema & Bologna & Future & Talk & Future & Genoa \\
\hline Inventor & NASA & Rome & Meeting & Use & Androids & Learn & Physiotherapy \\
\hline Sick & Hire & Movie & Museum & Born & Solve & Talk & Opera \\
\hline Help & To land & Festival & Milan & Revolution & Think & Will & Germany \\
\hline $\mathrm{Nao}$ & True & Robot Trains & Street & Person & Second & Machine & Competition \\
\hline Competition & Run & TV & Digital & The first & $\mathrm{Nao}$ & Now & Conquer \\
\hline $\begin{array}{l}\text { Personal and family } \\
\text { robots }\end{array}$ & Science & Threat & Work-Other & $\begin{array}{l}\text { Work Controversies } \\
\text { and Policies }\end{array}$ & Work Skills & Other & \\
\hline Home & Study & War & Industry & Job & Arrive & Robot & \\
\hline Dog & Philae & Stop & Work & Steal & Surgical & Challenge & \\
\hline Family & Water & Fear & Job & Worker & Intervention & Kitchen & \\
\hline Entry & Mars & Have & Factory & Employment & Pepper & World & \\
\hline Ready & European & Killer & Avatar & Substitute & Surgery & Varese & \\
\hline UE & Marine & Project & Water & Tax & Hospital & Build & \\
\hline Run & Fish & UE & Fire & Bill Gates & Operating & Hand & \\
\hline Open & Photo & Duty & Japanese & Salvini & Tumor & News & \\
\hline European & Scientist & Launch & Nurse & Risk & Elderly & Drones & \\
\hline Butler & NASA & Hour & Market & Pay & Walk & Year & \\
\hline
\end{tabular}




\section{Discussion}

The results have shown that online news stories on robots have increased over time, doubling in the five years considered in the study. Such a noticeable growth is confirmed by the percentage of robot news in the total number of news items published. The Facebook engagement follows the same path, so validating the idea of an increasing interest towards robots among the Italian online public and suggesting they no longer appear a topic people perceive far from their lives. In turn, familiarity with robots is reinforced by their increasing presence in online news stories (Sundar et al., 2016).

The study has highlighted that online news media have introduced a variety of topics over the years. Most of them have focused on issues related to robots' work skills and employment. This is comprehensible since robots have been used in work activities and industrial production for many years. However, new topics have also been introduced in the Italian online news, such as those describing social robots and their human-like abilities (see for example the news concerning robots working as butler, the one teaching hospital patients not to be afraid, and the music director one). The use of robots is moreover described in increasingly diversified social spheres, such as festivals and exhibitions, school, and personal and family use. Thus, the landscape of robot-related news stories and their cultural representations is changing, in that nowadays it increasingly describes robots' applications in many different social sectors (Mejía, Kajikawa, 2019).

It has emerged that topics identified through text clustering are marked by different grades of interaction on Facebook. The news with the highest engagement concerns the experiment of two robots that started talking to each other in an unknown language (Facebook engagement: 67,819). Then, there is news on issues such as the future, human-robot relationship, and workrelated controversies and policies. The news topic representing robots as a physical threat collected only 7,705 interactions on Facebook. These results raise some questions about the social sentiment toward robots. Although fears that robots might steal human jobs and become autonomous and uncontrollable seem to persist, news representing robots as a threat is less than expected. This might support the idea that threatening representations of robots (Mori, 1970, 2012; Strait, 2017) are not so widespread or engaging. This was not a specific area of inquiry of the current study and further research is needed to assess the attitude toward robots, and how 
and why it has changed through the years. However, some observations are possible. For example, there might be a lack of awareness regarding risks associated with the use of robots - for example war robots - due to a scarce media coverage of the topic. However, a stronger explanation has to do with socialization practices promoting human-robots coexistence: a lot of news revolves around the use of robots in teaching activities, entertainment industry, festivals, exhibits and in the personal and familial sphere. These activities promote a gradual, positive integration of robots in everyday life. Considering that many people still have limited direct experience with robots, also media play a central role in promoting a positive representation of robots. Finally, a significant role is played, and will be played in the future, by marketing activities aimed at promoting positive attitudes toward consumer robotics products.

\section{Conclusions}

The purpose of this paper has been to trace the trends in the online news media coverage and Facebook engagement of robot-related news stories and to identify the most covered and engaged topics.

With this paper, a new approach to the study of robots from a social science perspective has been introduced. The approach, types of data and computational methods used in this research have already been applied in news media studies related to political (Giglietto et al., 2019a, 2019b; Righetti et al., 2019), health (Lovari et al., forthcoming) and other present-day sociocultural issues (Righetti, 2016). This study demonstrated that other social science topics can benefit from methods and techniques able to study the online information ecosystem considering both online news sources and social media networks.

This research has inevitably some limitations. Although a high number of news media has been considered, it would be worth including other media sources. This limitation depends in part on the Media Cloud database that currently includes a partial number of Italian social media resources, but also on the structure of the Internet. Indeed, achieving completeness is a tough challenge in an online environment where news sources continuously appear and disappear. Besides considering a larger number of media sources, the analysis can be improved by extending the number of years and social media platforms taken into consideration. Moreover, in a few years the study could be replicated in order to identify new topics and their change over time. 
Despite these limitations, this research has been the first effort to analyze Italian news media and social media trends and topics of robot-related news stories.

\section{References}

AGCOM (2019), Osservatorio sulle comunicazioni N. 1/2019. Available at https://www.agcom.it/.

Aggarwal, C. C., \& Zhai, C. (2012). Mining text data. Springer Science \& Business Media.

Bartneck, C., Nomura, T., Kanda, T., Suzuki, T., \& Kato, K. (2005, April). Cultural differences in attitudes towards robots. In Proc. Symposium on robot companions (SSAISB 2005 convention) (pp. 1-4).

Bartneck, C. (2013). Robots In The Theatre And The Media. Proceedings of the Design \& Semantics of Form \& Movement (DeSForM2013), Wuxi pp. 64-70

Benoit K. (2018). quanteda: Quantitative Analysis of Textual Data, version 1.3.4, http://quanteda.io

Bissell, D., Birtchnell, T., Elliott, A., \& Hsu, E. L. (2018). Autonomous automobilities: The social impacts of driverless vehicles. Current Sociology, 0011392118816743.

Broadbent, E., Stafford, R., \& MacDonald, B. (2009). Acceptance of healthcare robots for the older population: Review and future directions. International journal of social robotics, 1(4), 319.

Cleveland R.B., Cleveland W.S., McRae J.E., and Terpenning I. (1990), STL: A Seasonal-Trend Decomposition Procedure Based on Loess. Journal of Official Statistics, 6, 3-73.

Dekker, F., Salomons, A., \& Waal, J. V. D. (2017). Fear of robots at work: the role of economic self-interest. Socio-Economic Review, 15(3), 539-562.

Feldman, R., \& Sanger, J. (2007). The text mining handbook: advanced approaches in analyzing unstructured data. Cambridge university press.

Fiebert, M. S., Aliee, A., Yassami, H., \& Dorethy, M. D. (2014). The life cycle of a Facebook post. The Open Psychology Journal, 7(1).

Fortunati, L., Esposito, A., \& Lugano, G. (2015). Introduction to the special issue "Beyond industrial robotics: Social robots entering public and domestic spheres". 
Fortunati, L. (2018). Robotization and the domestic sphere. New Media \& Society, 20(8), 26732690.

Fortunati, L., Sarrica, M., Ferrin, G., Brondi, S., \& Honsell, F. (2018). Social robots as cultural objects: The sixth dimension of dynamicity? The Information Society, 34(3), 141-152.

Garrison, B. (2001), 'Diffusion of online information technologies in newspaper newsrooms', Journalism and New Technologies, 2(2): 221-239.

Giglietto, F., Iannelli, L., Rossi, L., Valeriani, A., Righetti, N., Carabini, F., ... \& Zurovac, E. (2018). Mapping Italian News Media Political Coverage in the Lead-Up to 2018 General Election. Available at SSRN 3179930.

Giglietto, F., Valeriani, A., Righetti, N., \& Marino, G. (2019a). Diverging patterns of interaction around news on social media: insularity and partisanship during the 2018 Italian election campaign. Information, Communication \& Society, 1-20.

Giglietto, F., Valeriani, A., Righetti, N., Marino, G. (2019b). Ogni comunità è un'isola? Polarizzazione, amplificazione e reframing dell'informazione sui social media. In Bentivegna, S., Boccia Artieri, G., Niente di nuovo sul fronte mediale. Agenda pubblica e campagna elettorale. Franco Angeli, Milano

Hornyak T. N. (2006). Loving the Machine: The Art and Science of Japanese Robots. Kodansha International, Tokyo.

Yousuf, M., Haque, M. M., \& Islam, M. K. (2019). Online niches of English-language newspapers in Bangladesh: Analyzing news stories and user engagement on Facebook. Newspaper Research Journal, 40(1), 106-126.

Levy, D. (2009). Love and sex with robots: The evolution of human-robot relationships. New York.

Li H, Fang W, An H, Huang X (2015) Words Analysis of Online Chinese News Headlines about Trending Events: A Complex Network Perspective. PLoS ONE 10(3): e0122174. https://doi.org/10.1371/journal.pone.0122174

Ljungblad, S., Kotrbova, J., Jacobsson, M., Cramer, H., \& Niechwiadowicz, K. (2012, February). Hospital robot at work: something alien or an intelligent colleague? In Proceedings of the ACM 2012 conference on Computer Supported Cooperative Work (pp. 177-186). ACM.

Lovari, A., Martino, Righetti, N. (forthcoming). Blurred Shots: Investigating Information Crisis around Vaccination in Italy. American Behavioral Scientist 
Mejía, C., \& Kajikawa, Y. (2019). Technology news and their linkage to production of knowledge in robotics research. Technological Forecasting and Social Change, 143, 114-124.

Michalke M. (2017). koRpus: An $R$ Package for Text Analysis, version 0.10-2, https://reaktanz.de/?c=hacking\&s=koRpus

McFarland, M. (2019). FedEx turns to Segway inventor to build delivery robot. CNN Business. February 27, 2019.https://edition.cnn.com/2019/02/27/tech/fedex-delivery-robot/index.html Mori, M. (1970). The uncanny valley. Energy, vol. 7, no. 4, pp. 33-35 (in Japanese)

Mori, M., MacDorman, K. F., \& Kageki, N. (2012). The uncanny valley [from the field]. IEEE Robotics \& Automation Magazine, 19(2), 98-100.

Nicolosi G. (2011). Robot. La macchina, il corpo, la società. Editpress, Firenze.

Operto F. (2011). Robotica, nuova scienza, in G. Nicolosi (ed.), Robot. La macchina, il corpo, la società. Editpress, Firenze.

Pew Research Center (2014). "AI, Robotics, and the Future of Jobs". Available at: http://www.pewinternet.org/2014/08/06/future-of-jobs/

Pew Research Center (2017). "Automation in Everyday Life". Available at: https://www.pewinternet.org/wpcontent/uploads/sites/9/2017/10/PI_2017.10.04_Automation_FINAL.pdf.

Moscovici, S. (2001). Social representations: Essays in social psychology. Washington Square, New York: NYU Press.

Muscato G. (2011). 'Robotica e Società', in G. Nicolosi (ed.), Robot. La macchina, il corpo, la società. Editpress, Firenze.

R Core Team (2018). R: A Language and Environment for Statistical Computing, R Foundation for Statistical Computing. Vienna, Austria, https://www.R-project.org/

Ratinaud, P. (2009). IRaMuTeQ: Interface de R pour les Analyses Multidimensionnelles de Textes et de Questionnaires. Téléchargeable à l'adresse: http://www. iramuteq. org.

Righetti, N. (2016). L'inchiostro digitale è vegano? La rappresentazione del veganismo sulla stampa. Cambio. Rivista sulle Trasformazioni Sociali, 6(11), 181-194.

Righetti, N. (2019). Sfide e limiti del veganismo. Vegefobia, mass media e mercato. 
Righetti, N., Giglietto, F., \& Marino, G. (2019). L'Europa fra casa e gabbia. Tono, frame ed engagement delle notizie sulle istituzioni europee nei mesi precedenti le elezioni 2018. Problemi dell'informazione, 44(1), 87-116.

Righetti, N. (2018). Tra sacro e vegano, Ferrari Editore. Corigliano - Rossano.

Strauss, A., Corbin, J. (1998) Basics of Qualitative Research: Techniques and Procedures for Developing Grounded Theory, London, Sage publications.

Strait, M. K., Aguillon, C., Contreras, V., \& Garcia, N. (2017, August). The public's perception of humanlike robots: Online social commentary reflects an appearance-based uncanny valley, a general fear of a "Technology Takeover", and the unabashed sexualization of femalegendered robots. In 2017 26th IEEE International Symposium on Robot and Human Interactive Communication (RO-MAN) (pp. 1418-1423). IEEE.

Sundar, S. S., Waddell, T. F., \& Jung, E. H. (2016, March). The Hollywood robot syndrome: media effects on older adults' attitudes toward robots and adoption intentions. In the Eleventh ACM/IEEE International Conference on Human Robot Interaction (pp. 343-350). IEEE Press.

Taipale, S., de Luca, F., Sarrica, M., Fortunati L. (2015), 'Robot Shift from Industrial Production to Social Reproduction', in J. Vincent, J., Taipale, S., Sapio, B., Lugano, G., Fortunati, L. (2015) (Eds.), Social Robots from a Human Perspective, Springer: London, pp. $11-24$.

Tartaglia S., Gonella R., Rollero C. (2006), Analisi di un corpus di titoli di giornale: un confronta tra strategie, JADT'06, Bès journées internationales d'analyse statistique des données textuelles (2 volumes).

Tsuchiya, J. (2015), Robots between nature and culture: Symbiotic Japanese Thought, Ba3ylon (online Journal), No.12.

Vercelli, A., Rainero, I., Ciferri, L., Boido, M., \& Pirri, F. (2018). Robots in Elderly Care. DigitCult-Scientific Journal on Digital Cultures, 2(2), 37-50.

Vestergård, G.L. (2011), From journal to headline: the accuracy of climate science news in Danish high-quality newspapers, Jcom [Journal of Science Communication] 10(02).

Viviani, D. (2012). The desire for omnipotence and the illusion of hyperreality: the strange case of the virtual hostess. Italian Sociological Review, 2(2), 76. 
Vitanza, A., D’Onofrio, G., Ricciardi, F., Sancarlo, D., Greco, A., \& Giuliani, F. (2019). Assistive Robots for the Elderly: Innovative Tools to Gather Health Relevant Data. In Data Science for Healthcare (pp. 195-215). Springer, Cham.

Webster, J.G. (2014). The Marketplace of Attention: How Audiences Take Shape in a Digital Age. Cambridge, MA: The MIT Press. 